\title{
Strategic Instruments to Choose Foreign Target Markets
}

Submitted 23/08/19, $1^{\text {st }}$ revision $19 / 09 / 19,2^{\text {nd }}$ revision $11 / 10 / 19$, accepted $27 / 11 / 19$

\author{
N.A. Dimitriadi ${ }^{1}$, O.N. Voronkova ${ }^{2}$, S.S. Galazova ${ }^{3}$
}

\begin{abstract}
:
Purpose: The paper aims to elaborate the principles and the authors' original method to choose target markets of textile and fibers manufacturers when internationalizing their economic activity. The decision on foreign target markets must be very reasonable as having chosen a new foreign market the company put a lot of resources into it.

Design/Methodology/Approach: The authors suggest to take into account three factors for the most perspective foreign markets for export interventions. The cash flow in foreign trade by specific materials (textiles and fibers) was estimated by each country - to select the countries depending on textiles and fibers import. Among those countries the markets' attractiveness was estimated by their size and growth intensity. After that general opportunities of doing business by Russian companies in the country were estimated using a complex index calculated on a basis of data characterizing import from Russia volume and its dynamics, transport accessibility, GDP Volume and Dynamics.

Findings: The paper contains a set of data characterizing the most perspective countries for Russian textile companies export expansion - Cambodia, Bangladesh, Sri Lanka, Iran, Saudi Arabia, Morocco, Nicaragua, Viet Nam. Central and Eastern European countries (Romania, Poland, Slovenia), United Kingdom, USA, Canada are attractive from a point of view of potential prospects of business development in the country, however cooperation with them may be difficult due to some serious barriers on entering the markets.

Practical Implications: The matrix can be used in managerial practices of different companies oriented on their international business activities expanding. The results of the new methods implementation (the list of the most perspective foreign markets) can be used by for management of the Russian textile companies oriented on foregn markets.

Originality/Value: The paper contains a new method of foreign target markets choosing and a new strategic instrument - the matrix of export expansion markets choosing.
\end{abstract}

Keywords: market attractiveness, strategic instrument, market selection, target market, export expansion.

JEL code: L10, L22.

Paper Type: Commentary note: Business Strategy.

${ }^{l}$ Professor, Rostov State University of Economics, Rostov-on-Don, Russian Federation, ndimitriadi@yandex.ru

${ }^{2}$ Associate Professor, Professor, Rostov State University of Economics, Rostov-on-Don, Russian Federation, vipoksanka@yandex.ru

${ }^{3}$ Professor, Professor of the Department of Economics, North Ossetia State University, Vladikavkaz. 


\section{Introduction}

The internalization of commercial companies' activities is able not just to increase a level of their profitability (Buckley and Casson, 1976), but can be a way to their competitiveness increasing (Boshkov and Drakulevski, 2019). As a business environment dynamic transformation has involved an international textile industry (Mikhnevich, 2017), a strategic approach (Grant, 2008) to the industry managing should be implemented; it includes an internalization of business activities. An importance of proper internationalization strategies is emphasized by contemporary specialists (Ghemawat, 2003; Peng, Wang and Jiang, 2008). Target markets choosing is one of the most important strategic decisions (Dimitriadi, Aroyan and Khodareva, 2013; Callaghan and Morley, 2002), when making them the specialist should estimate markets attractiveness (Lamben, 2004) and resources accessible for usage (Trofimenko and Tikhomirova, 2016; Thalassinos et al., 2013; Thalassinos, 2007). The purpose of this research is an elaboration of target markets choosing principles for export expansion of the Russian textile manufacturers.

\section{Methods}

Initially all factors which should be considered and analyzed when choosing the foreign target market were divided into two large groups:

- the factors of attraction (attracting managers to the market);

- the factors of limitation (making activities on the market difficult).

A detailed analysis of the first group allowed to divide the factors into two smaller categories:

- a cash flow in foreign trade (including a cash flow by specific materials related to a profile of the company making the strategic choice);

- different target market choosing criteria related to the market's size, competitors' activities, etc.

The cash flow in foreign trade is very important as entering the market could be facilitated when the market depends on import of some important materials; if export dominates it could be very difficult to enter the market even if the market is very attractive (for instance due to its big size). In the same time a cash flow balance of trading operations by specific materials with a concrete country is very important. The balance characterizes a level of support of the industry by the government and, in the same time, reflects existing opportunities of entering the market by foreign suppliers including Russian companies.

An attractiveness of the market depends on several factors which should be selected from a point of view of objectives set by the management produced a decision about the foreign market expansion. Very often an important role plays two factors: 
- a size of the market (as the company is oriented on achieving of big sales volume during some period of its export activity);

- an intensity of growth of a size of the market (as the company tries to be integrated into the market having relatively low costs and, in the same time, good perspectives of business growth - with the market size increasing).

Generally, target market choosing criteria are based on estimation of market factors which can influence on results of the company activities as well as political, law and socio-cultural ones:

1.Usually when examining the market capacity, the specialist must consider the following factors:

$\checkmark$ market size and tendencies of its changing in a country or in several countries;

$\checkmark$ market shares taken by companies competing on the market;

$\checkmark$ manufacturing output and local consumption of the goods in relation to an export volume;

$\checkmark$ market size and related volumes/quantities of different products manufactured/used as well as ways of usage;

$\checkmark$ possible strategies for entering the market and the perspectives of the market's size growth.

2.The market landscape constructing:

$\checkmark$ current market situation and main market tendencies;

$\checkmark$ technological picture in the industry and a readiness of the market for taking new technologies;

$\checkmark$ orientation of the market on new products appearance;

$\checkmark$ peculiarities of law and political environment influencing on new products and technologies introduction;

$\checkmark$ current and expected issues as well as business development opportunities in each market sector (Dimitriadi, 2006).

Looking at the political factors influencing the target market choosing we can conclude that peculiarities of the political system could be very significant. For instance, strong governments' influence in Uzbekistan and Turkmenistan entails restrictions for entering the markets by foreign suppliers accompanied by a big room for improvement for the range of goods (manufactured and exported) planning. In the same time existing political relations could become a strong basis for foreign market entering. For instance, signing preferential agreements between Russian Federation and Viet Nam, Uzbekistan and Iran appear as a basis for a complementarity of international trade.

The most important of the listed above factors were converted into a two-criteria factor «market size/market growth» (forming one (vertical) of the two axes of the matrix developed by the authors); calculating the factor can be a base for investments perspectives estimating from a point of view of results of the market 
peculiarities examining. In addition to that the second (horizontal) axe of the matrix is presented by a multi criteria indicator characterizing macroeconomic, political (including foreign policy), law and socio-cultural factors.

Figure 1. Matrix of export expansion markets choosing.

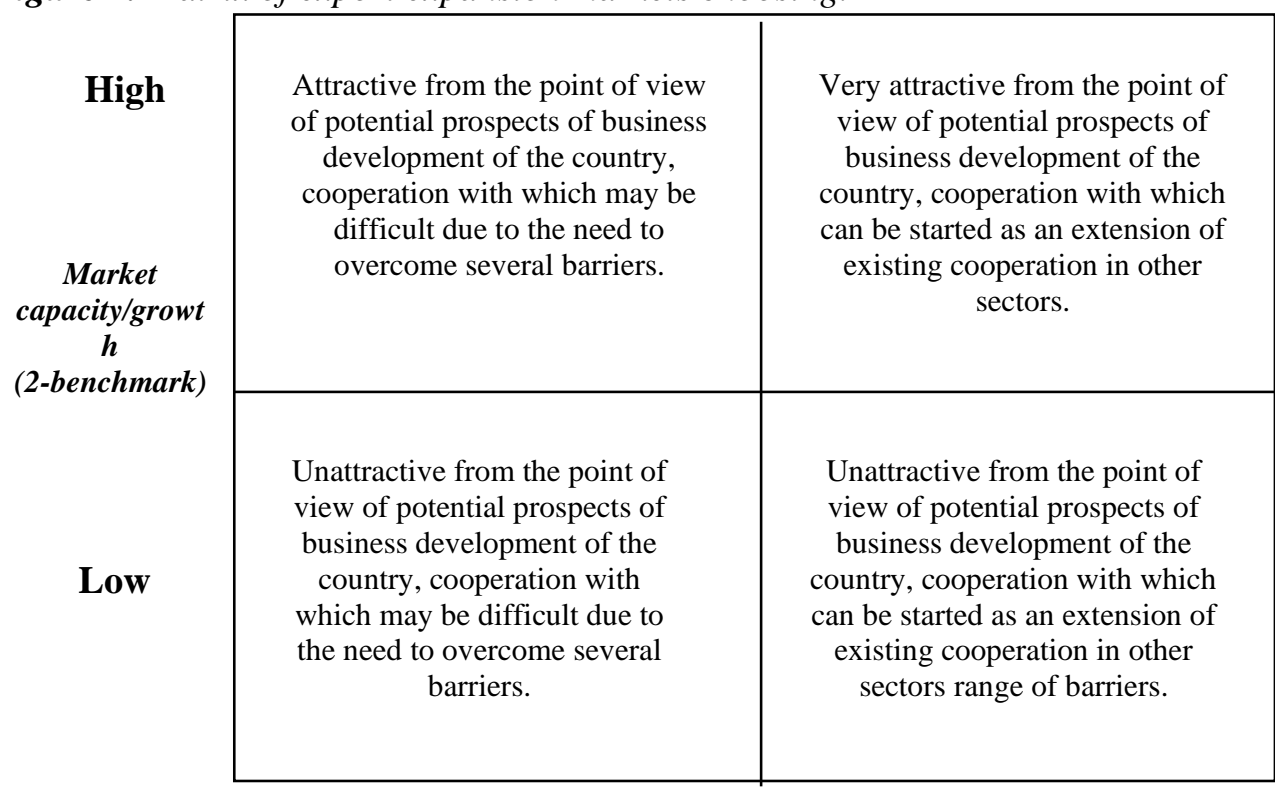

Low

High

\section{Level of cooperation with Russia (multi criteria indicator)}

The combination of the two described above factors allows to create a matrix with for standard quadrants (Figure 1):

- the markets in the lower left quadrant are unattractive due to the low level of them attractiveness and to a necessity to overcome several barriers on entering them;

- the markets in the lower right quadrant are unattractive due to the low level of them attractiveness;

- the markets in the upper left quadrant are attractive due to the high level of them attractiveness despite of a necessity to overcome several barriers on entering them (however, if the barriers are too high or numerous the level of attractiveness can decrease);

- the markets in the upper right quadrant are very attractive due to their size/growth and from the point of view of real opportunities related to an extension of existing cooperation in other sectors. 
Initially cash flow in foreign trade by specific materials (textiles and fibers) was estimated by each country. Then foreign textile markets were examined by their size and growth intensity (Dimitriadi, 2006; Voronkova, 2018) and general level of each country international cooperation with Russia was evaluated using a complex index calculated (for each country) by data characterizing import from Russia volume and its dynamics, transport accessibility, GDP volume and its dynamics, and some other indexes (Exportcenter, 2018). Markets growth intensity was compared with the basis of textile production records in Excel program according to the codes of HS in every country, exclusive its export from the following countries, plus the import in threeyears dynamics.

Databases of international organizations were used to obtain data on the textile industry - UNCTAD (2017), World Bank (WTS, 2019), WTO (2019), ICT (2019), also international foreign trade statistical databases (Trademap, 2018; Ereport, 2018; Comtrade, 2018; EWORLD, 2014). Specialized portals on textiles (F2F, 2018; JS, 2019; IDTECHEX, 2018; , PAULINEVANDONGEN, 2018) as well as Russian databases: the Russian Export Center (2018)), Ministry of industry and trade (MITR, 2018), Federal service of statistics (GKS, 2018) were used.

\section{Empirical Results and Conclusions}

Based on the results of this research the countries with the most negative cash flow in foreign trade by specific materials (textiles and fibers) were identified (Table 1).

Table 1. Countries with economics, depending up the textile's import, 2017

\begin{tabular}{|l|l|}
\hline Trade position & $\begin{array}{l}\text { Countries with the most negative cash flow } \\
\text { in foreign trade by textiles and fibers }\end{array}$ \\
\hline \multicolumn{1}{|c|}{ 1 } & \multicolumn{1}{c|}{$\mathbf{2}$} \\
\hline $\begin{array}{l}5407 \text { Woven fabrics of synthetic filament } \\
\text { yarn, including woven fabrics obtained } \\
\text { from materials of heading no. 5404 }\end{array}$ & $\begin{array}{l}\text { Vietnam, Bangladesh, Mexico, USA, Brazil, } \\
\text { Indonesia, Romania, Poland, Saudi Arabia, } \\
\text { Iran, Malaysia, Morocco, Russia. }\end{array}$ \\
\hline $\begin{array}{l}\text { 6006 Fabrics; knitted or crocheted fabrics, } \\
\text { other than those of headings } 60.01 \text { to } \\
60.04\end{array}$ & $\begin{array}{l}\text { Vietnam, Indonesia, Cambodia, Sri Lanka, } \\
\text { Bangladesh, Jordan, Mexico, Morocco, } \\
\text { Nicaragua, Philippines, Romania, Russia. }\end{array}$ \\
\hline $\begin{array}{l}5603 \text { Nonwovens; whether or not } \\
\text { impregnated, coated, covered or } \\
\text { laminated, n.e.s. }\end{array}$ & Canada, Belgium, UK, Japan, Hong Kong. \\
\hline $\begin{array}{l}5208 \text { Woven fabrics of cotton, containing } \\
85 \% \text { or more by weight of cotton, } \\
\text { weighing not more than } 200 \mathrm{~g} / \mathrm{m} 2 .\end{array}$ & $\begin{array}{l}\text { Bangladesh, Vietnam, USA, Indonesia, Sri } \\
\text { Lanka, Tunisia, Morocco, Romania, Poland, } \\
\text { Mexico, Kenya, Russia. }\end{array}$ \\
\hline $\begin{array}{l}5209 \text { Woven fabrics of cotton, containing } \\
85 \% \text { or more by weight of cotton, } \\
\text { weighing more than } 200 \mathrm{~g} / \mathrm{m} 2 .\end{array}$ & $\begin{array}{l}\text { Bangladesh, Vietnam, Tunisia, Sri Lanka, } \\
\text { Cambodia, Mexico, Indonesia, Morocco, }\end{array}$ \\
\hline $\begin{array}{l}5516 \text { Woven fabrics of artificial staple } \\
\text { fibres. }\end{array}$ & Nicaragua, Romania, Russia. \\
\hline
\end{tabular}


Then the authors put the data into the Matrix of export expansion markets choosing. The right intake of the matrix allows to allocate the top concerns in the context of export expansion to foreign markets with the highest levels of market size and market growth as well as a highest general level of international cooperation of the analyzed country with Russia. According to conducted analysis, the most attractive countries for the textile export from Russia are: Viet Nam (the $1^{\text {th }}$ position in textile export in 2017), Cambodia, Bangladesh, Sri Lanka, Iran, Saudi Arabia, Morocco, Nicaragua, Central and Eastern European countries (Romania, Poland, Slovenia), United Kingdom, USA, Canada (Figure 2).

Figure 2. Matrix of export expansion markets choosing for the Russian textile company.

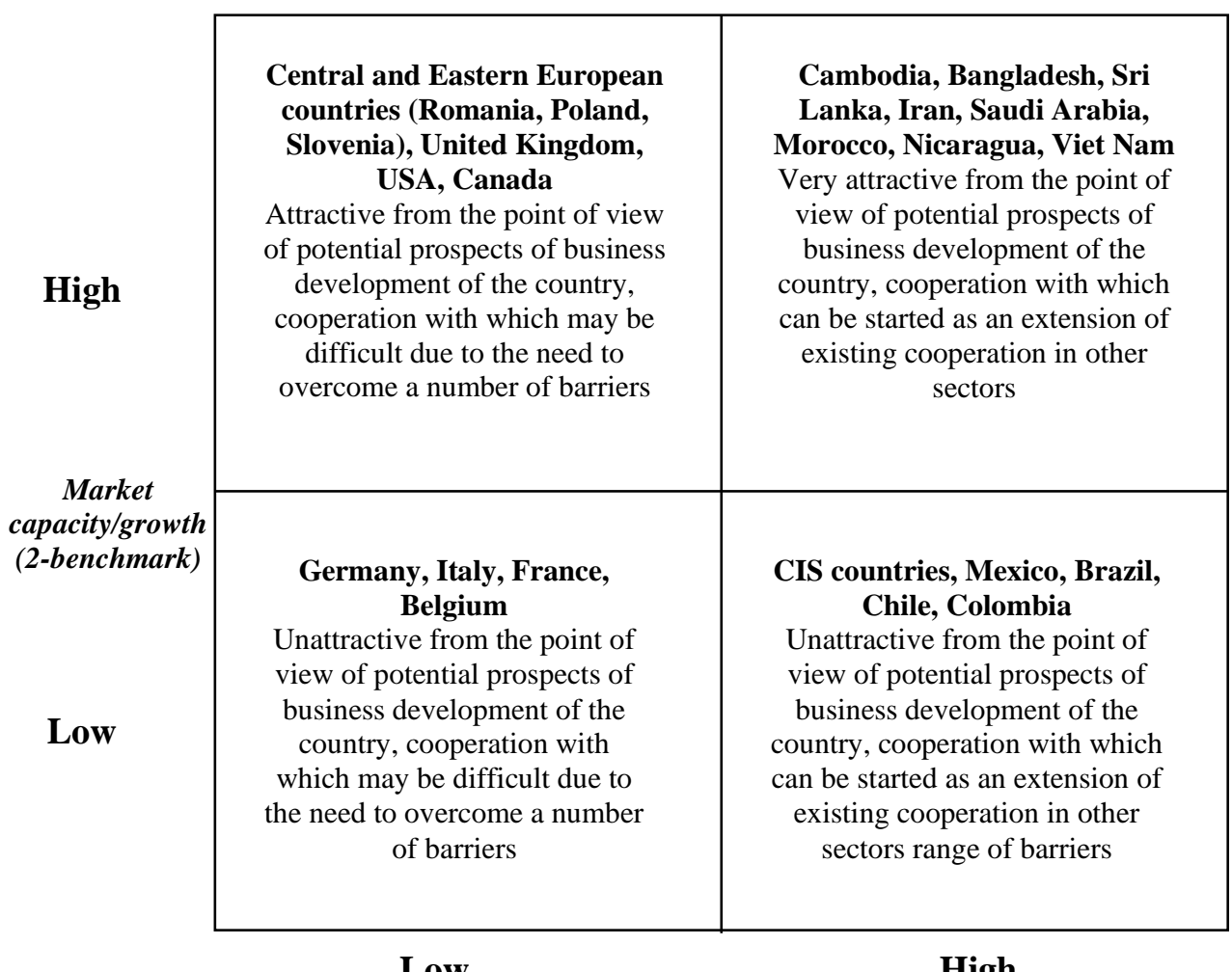

\section{Level of cooperation with Russia (multi criteria indicator)}

All those countries are perspective for the export, according to all the criteria in the correlation with the trends of the import flow indicated earlier. Altogether, the intake of the suggested approach to target export expansion markets choosing allows arranging the marketing strategy for entering the markets and the manufacturing 
strategy/product portfolio developing. Additionally, implementation of the approach suggested could assist to elaborate and to adopt the corporative strategy to the contractile cycles of the economic development.

\section{References:}

ASIAIPEX. 2019. IP Exchange platform. Available online: asiaipex.com.

BI. 2018. Business insider review. Available online: businessinsider.com.

Boshkov, T., Drakulevski, L. 2019. The Role of Strategic Management in SMEs: International Business Up-Grading. International Journal of Information, Business and Management, 11(1), 34-43.

Buckley, P.J., Casson, M. 1976. The Future of the Multi-national Enterprise. London, Macmillan.

Callaghan, B., Morley, C. 2002. RMIT University. The Hierarchy of Target Market Selection Criteria. ANZMAC 2002 Conference Proceedings, 761-767.

Comtrade. 2018. UN Comtrade Database. Available online: https://comtrade.un.org.

Dimitriadi, N.A. 2006. On administration of sales department: applying the marketing technologies. Rostov-on-Don.

Dimitriadi, N.A., Aroyan, N.M., Khodareva, T.A. 2013. On the performance of sales management frameworks in Russian entrepreneurial entities. Management and Business Administration, 4, 124-136.

Ereport. 2018. Global trade \& markets. Available online: http://www.ereport.ru.

EWORLD. 2014. Global fashion \& textile market overview. Available online: http://megaeworld.com/pub/section100519/element2390971/.

Exportcenter. 2018. Ranking of the attractiveness of foreign country markets for Russian exports of non-primary non-energy goods. Available online: https://www.exportcenter.ru/international markets/country rating/ranking_2018.pdf.

F2F. 2018. World fashion trends. Available online: https://www.fibre2fashion.com/.

Ghemawat, P. 2003. Focused Issue: The Future of Multinational Enterprise: 25 Years Later. Journal of International Business Studies, 34(2), 138-152.

GIA. 2018. Global industry analysts. Available online: strategyr.com.

GIZMAG. 2018. New technology \& science news. Available online: gizmag.com.

GKS. 2018. Federal state statistics service database. Available online: gks.ru.

Globalspec. 2019. Business and technology of electronics. Available online: electronics360.globalspec.com.

Globenews. 2018. Global business news. Available at: globenewswire.com.

Grant, R. 2008. Modern strategic analysis. Saint Petersburg, Piter publ.

HTI. 2018. Health tech insider. Available online: healthtechinsider.com.

ICT. 2019. Market analysis tools portal. Available online: https://marketanalysis.intracen.org.

IDTECHEX. 2018. Market research, business intelligence and events on emerging technology. Available online: idtechex.com.

JS. 2019. Just-style's online magazine. Available online: Just-style.com.

Lamben, Zh.Zh. 2004. Market-oriented management. Saint Petersburg, Piter publ.

Mikhnevich, S.I. 2017. Trade liberalization as a factor of accelerating the innovative development of the economy (on example of the textile industry). Trade policy, 2(10), 9-18.

MITR. 2018. Official website of Ministry of industry and trade of Russia. Available online: www.minpromtorg.gov.ru. 
PAULINEVANDONGEN. 2018. Pauline van Dongen design. Available online: paulinevandongen.nl.

Peng, M., Wang, D., Jiang, Y. 2008. An institution-based view of international business strategy: a focus on emerging economies. Journal of International Business Studies, 39, 920-936.

Pocketlint. 2019. The best technology and gadgets overview. Available online: pocketlint.com.

RIS. 2019. Consumer market analytics. Available online: apparel.edgl.com.

Thalassinos, I.E., Venediktova, B., Staneva-Petkova, D. 2013. Way of Banking Development Abroad: Branches or Subsidiaries. International Journal of Economics and Business Administration, 1(3), 69-78.

Thalassinos, I.E. 2007. Trade Regionalization, Exchange Rate Policies and EU-US Economic Cooperation. European Research Studies Journal, 10(1-2), 111-118.

Trademap. 2018. Trade statistics for international business development. Available online: https://www.trademap.org.

Trofimenko, E.Yu., Tikhomirova, I.S. 2016. Market analysis and choosing of new target markets. Economics and business: theory and practice, 9, 87-90.

UNCTAD. 2017. Trade and development report. Available online: http://unctad.org/en/PublicationsLibrary/tdr2017overview_ru.pdf.

Voronkova, O.N. 2018. Concept of analysis and choosing the foreign market by exportoriented Russian companies. In: Fundamental and applied research: accounting, analysis and audit. Rostov-on-Don, RSUE.

Wareable. 2019. The latest news from the world of smartwatches, fitness tracking, sports tech - as well as health, VR and augmented reality. Available online: wareable.com.

WTO. 2019. World trade organization website. Available at: https://www.wto.org.

WTS. 2019. World integrated trade solutions. Available online: http://wits.worldbank.org. 